Chirurgia (2018) 113: 227-233

No. 2, March - April

Copyright@ Celsius

http://dx.doi.org/10.21614/chirurgia.113.2.227

\title{
Reintervention Rate Following Emergency Surgery for Crohn Disease
}

\author{
Iulian Slavu', Lucian Alecu', Adrian Tulin', Daniela Mihaila', Vlad Braga', Theodor Voiosu², Luminița Tomescu', \\ Silviu Constantinoiu ${ }^{3}$
}

${ }^{1}$ General Surgery Clinic, Prof. Dr. Agrippa Ionescu Emergency Clinical Hospital, Bucharest, Romania

${ }^{2}$ Gastroenterology Department, Colentina Hospital, Bucharest, Romania

${ }^{3}$ General and Esophageal Surgery Clinic, Center of Excellence in Esophageal Surgery, Sf. Maria Clinical Hospital, Bucharest, Romania

Corresponding author:

Alecu Lucian, MD, PhD

Department of General Surgery

Agrippa Ionescu Emergency Hospital

Bucharest, Romania, 011356

E-mail: lucianalecu@yahoo.com
Received: 11.03 .2018

Accepted: 05.04.2018

\section{Rezumat}

Rata de reintervenție după chirurgia de urgență în boala Crohn

Obiectiv: Evaluarea impactului intervenției chirurgicale de urgență şi a recurenței postoperatorii asupra bolii Crohn (BC) şi monitorizarea evoluției postoperatorii precum şi diferiții factori care o pot influenta

Metodă: Informatiile privind 37 de pacienți consecutivi care au fost diagnosticați şi operați în situații de urgență pentru complicațile $\mathrm{BC}$ şi rata de recidivă (considerată a doua intervenție chirurgicală) au fost evaluate retrospectiv.

Rezultate: Riscul recidivei a fost mai crescut la bărbații cu vârsta sub 50 de ani şi la cei care au beneficiat de anastomoză în timpul primei intervenții, în timp ce stoma pare să reducă rata de recidivă. Durata medie până la recădere a fost de 2,3 ani, în timp ce un procent de $33 \%$ $(\mathrm{n}=12)$ au necesitat reinterventie.

Concluzii: Majoritatea pacienților cu BC vor suferi cel puțin o intervenție chirurgicală în timpul vieții lor şi o treime dintre ei vor recidiva necesitând a doua intervenție. Deşi tratamentul medical a cunoscut progrese mari indicatiile interventiilor chirurgicale în urgență au rămas neschimbate Vârsta pacienților, fumatul şi medicația postoperatorie influențează rata de recurență.

Cuvinte cheie: boala Crohn, chirurgie de urgență, reintervenție 


\begin{abstract}
Backround/Objective: To assess the impact of emergency surgery and postoperative recurrence in Crohn's disease (CD) and to evaluate the disease course while observing different factors that may influence it.

Methods: Information on 37 consecutive patients which were diagnosed and operated in emergency for CD complications and the the relapse rate (regarded as a second surgery) were retrospectively evaluated.

Results: The risk of relapse and second surgery was increased in males under 50 years and in those who benefited from an anastomosis during the first invervention while stomy seemed to reduce the rate of surgical relapse. The median duration until relapse was 2,3 years while a percentage of $33 \%$ required reintervention.

Conclusions: The majority of patients with CD will undergo at least one surgical intervention during their lifetime and one third of them will relapse requiring a second intervention. Although medical treatment has seen great advancements, surgery requirements have remained unchanged as the mainstay treatment in emergent complications of CD. The age of the patients, smoking status and the postoperative medication influence the rate of postoperative recurrence.
\end{abstract}

Key words: Crohn disease, emergency surgery, reintervention

\section{Introduction}

Crohn's disease (CD) is a chronic, idiopathic inflammatory pathology that can affect any part of the digestive tract but usually involves the terminal ileum. The inflammatory process starts with mucosal damage and progresses to granulomatous transmural inflammation that alternates between the affected regions and healthy ones. Clinical evolution of the disease is characterized by spontaneous phases of activity „flare-up” followed by remission periods. Approximately $75 \%$ of patients are exposed to these periods of activity while $10 \%$ will suffer from the chronic complications and the rest will be asymptomatic for long periods of time $(1,2)$. There is a wide range of medical treatments that can both prevent and reduce the activity episodes but the rate of patients requiring surgery has not changed over the years. Between $70 \%$ and $90 \%$ of patients with $\mathrm{CD}$ will require surgery, including those who have non-fistulating or non-penetrant phenotypes, while $39 \%$ will require reintervention $(3,4,5,6)$.

The indications for surgery reside mostly in complications which have a lifetime cumulative risk of $33.7 \%$ at 5 years after diagnosis and $50.8 \%$ at 20 years (7). Basic treatment in CD remains the medical care, while surgical treatment is reserved for cases with acute complications (obstruction, perforation, severe acute colitis) and chronic complications (stenoses, internal or external fistulas, abdominal masses) as well as disease forms refractory to conservative therapy (10). Acute operations (24h) or urgent interventions within 7 days carry the risk of an unfavorable outcome as the patient is not adquately prepared for these interventions, the surgery is most likely performed by trainees and the disease is severe. However, CD patients who presented with a acute episode can have a more favorable outcome because they did not receive medication and surgery is performed early so the disease is promptly controlled. The basis of surgery in $\mathrm{CD}$ is intestinal resection and rarely stricturoplasty (8). CD patients typically undergo intestinal resections in one of two settings: (a) elective operations that occur due to lack of efficacy of outpatient medical therapies or (b) emergent operations which are done for acute or life-threatening complications (e.g., small bowel obstruction) or failure of medical treatment. This distinction is important because patients undergoing emergency surgery are 
more likely to experience postoperative complications and postoperative mortality $(9,10)$. Onethird of patients diagnosed with Crohn's disease require surgery five years after diagnosis (11). Age, gender, disease localization, duration, and the presence of granulomas, all have different impacts on postoperative recurrence, and thus no sure risk factor, apart from smoking, has yet been established (12). CD can be aided by surgery but can not be cured by surgery. The main goal of the surgical interventions is to pass over the acute episode, to obtain the best quality of life and to conserve a larger portion of the digestive tract, as the probability of postoperative relapse at 10 years after the first intervention is between $25-45 \%$ (13).

Our study aims to evaluae the recurrence rate of $\mathrm{CD}$ patients operated in emergency settings and to evalutate the existence of factors that may increase or decrease it.

\section{Material and Method}

The present paper is a retrospective, multicenter study for which the retrieving of patient charts began with the year 2007. Inclusion criteria consisted in the diagnosis of $\mathrm{CD}$ and at least one surgical intervention for $\mathrm{CD}$. The patient files, paraclinical investigations, operative protocols and histopathological bulletins were reviewed and data regarding age, gender, date of diagnosis, medical treatment administered , postoperative recurrence and reintervention were collected. Surgery for CD was defined as surgical resection. The event of post operative recurence was considered to be in the day that the re-intervention took place.

\section{Statistical Analysis}

Statistical analysis was performed using IBM SPSS STATISTICS V20.0.

\section{Results}

A total of 37 patients have been identified which were operated in an emergency settings due to complications of CD. Of these, 15 were unaware of the disease at the time of surgery, while 22 were diagnosed preoperatively. The median age of the study group was 33,8 years with a minimum of 18 years and a maximum of 71 years with a standard deviation of 12 years. Smoking as a risk factor was identified in 19 patients.

The affected segments of the digestive tract can be observed in Table 1, of which the small intestine / terminal ileum was identified as the major organ interested in 20 cases. The most common reason for surgical intervention was

Table 1. Characteristics of the two groups (first surgery and relapse)

\begin{tabular}{|c|c|c|c|c|c|}
\hline First Surgery & & & Relapse Surgery & & \\
\hline Variable & Number & & Variable & Number & \\
\hline Gender & $\begin{array}{l}\text { male } \\
\text { female }\end{array}$ & $\begin{array}{r}29 \\
8\end{array}$ & Gender & $\begin{array}{l}\text { male } \\
\text { female }\end{array}$ & $\begin{array}{l}10 \\
3\end{array}$ \\
\hline Preop. medical treatment & $\begin{array}{l}\text { None } \\
\text { biologic } \\
\text { corticoids } \\
\text { imusupression }\end{array}$ & $\begin{array}{r}24 \\
2 \\
2 \\
8\end{array}$ & $\begin{array}{l}\text { Surgical indication } \\
\text { Relapse interval (years) } \\
\text { Relapse location }\end{array}$ & $\begin{array}{l}\text { Small intestine } \\
\text { Colon }\end{array}$ & $\begin{array}{l}\text { Intestinal obstruction } \\
2.3 \\
8 \\
3\end{array}$ \\
\hline Surgical indication & $\begin{array}{l}\text { obstruction } \\
\text { intestinal fistula } \\
\text { abdominal abcess }\end{array}$ & $\begin{array}{r}27 \\
6 \\
4\end{array}$ & & Perianal & 2 \\
\hline Disseased segment & $\begin{array}{l}\text { Colon } \\
\text { small intestine/terminal ileum } \\
\text { rectum }\end{array}$ & $\begin{array}{r}12 \\
20 \\
2\end{array}$ & & & \\
\hline First surgical intervention & $\begin{array}{l}\text { Stomy(colostomy/ileostomy) } \\
\text { Anastomosis }\end{array}$ & $\begin{array}{l}13 \\
24\end{array}$ & & & \\
\hline Relapse (required surgery) & & 13 & & & \\
\hline
\end{tabular}


instestinal occlusion in 27 cases, followed by fistula in 6 cases and intraabdominal abscess in 4 cases. In 13 patients the anastomosis was done during the first surgery while 24 patients were selected for stomy (colostomy or ileostomy). The median duration until reintervention was 2.3 years and $33 \%(n=13)$ of patients in the main group required reintervention. The postoperative medical therapy of CD patients at the time of reintervention was: corticotherapy - 3 patients, immunosuppression - 4 patients, biological therapy - 6 patients.

Patients were separated into two subgroups taking into acount the first procedure (anastomosis vs. stomy). Fig. 1 graphically represents survival without reintervention in the two subgroups using the Kaplan Meier curve. As we can see more reinterventions were necesary in the anastomosis subgroup during follow-up time. Most reinterventions took place between 40 to 60 months in both subgroups. There were $n=24$ patients in the anastomosis subgroup and $n=13$ in the stomy subgroup. Out of the 24 patients that underwent a surgical procedure that included anastomosis ten had reintervention. In the stomy subgroup, reintervention was necesary for three cases.

Taking into account the literature, which associates reintervention and age, we used the age 50-years as cut-off, distributing the patients in two subgroups: 20-50 years and over 50 years. Nine patients with relapse were in the
20-50 years subgroup while onlny three had over 50 years patien.

We represented using the Kaplan Meier curve the survival of patients without reintervention (Fig. 2). As the image shows, reinterventions in the 50-year-old group were spread over 60 months with a single patient who underwent reintervention at 140 months. The median time to reintervention in this subgroup was 73.71 months (95\% CI: 34.12-113.3).

In the 20-50 age group most reinterventions took place between 40 and 60 months after the first reintervention. Median time to reintervention was comparable to the other 80.24 months (95\% CI: 55.61-104.87) subgroup.

\section{Discussions}

The rate of postoperative relapse (defined as a secondary resection) in the literature is between $25 \%$ - $45 \%$ at 10 years after the first intestinal resection in CD patients (14). The data of the present study is in line with that of the literature, the rate of reintervention in the study group was $33 \%$ with an average duration until the reintervention of 2,3 years. Retrospective assessments of the surgical risk of recurrence in CD have several limitations such as low number of patients and short follow-up periods; these shortcomings have led to the impossibility to create a universally accepted consensus (15).

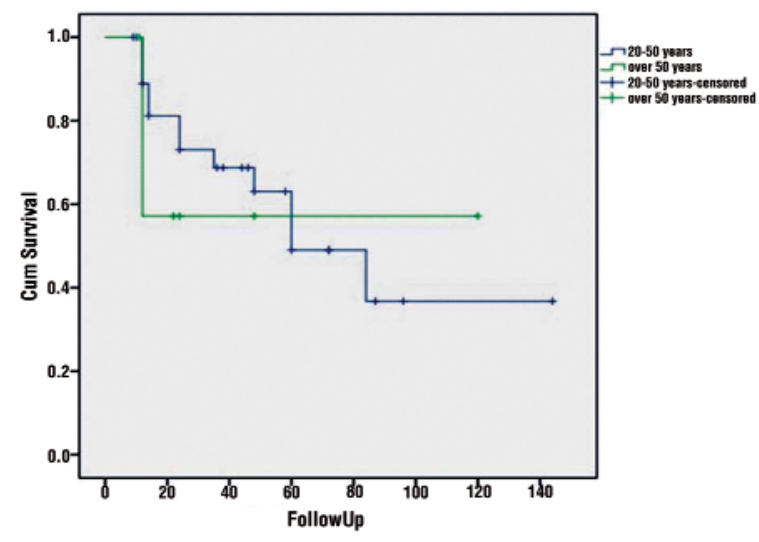

Figure 1. Kaplan Meier curve for survival without reintervention in 2 subgroups (stomy vs anastomosis)

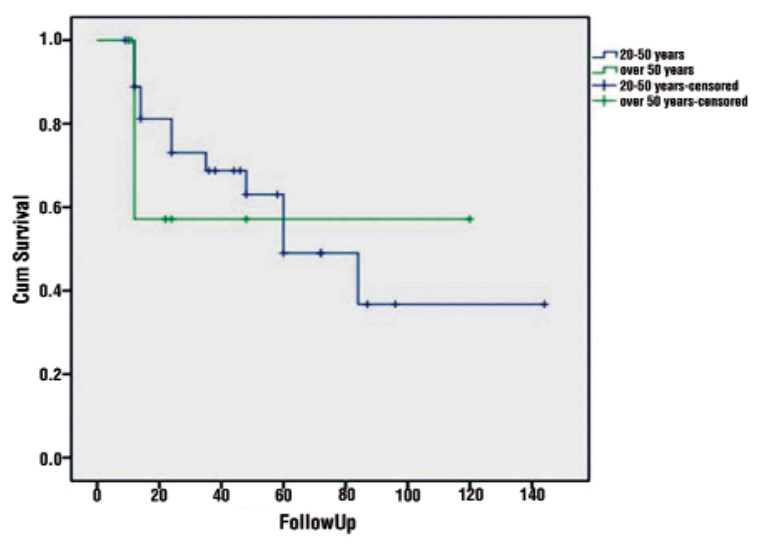

Figure 2. Kaplan Meier curve for survival without reintervention in 2 age subgroups (20-50 years vs over 50 years) 
Regarding the role of gender in the rate of recurence, Chardavoyne et al. identified a higher incidence of relapse in females but the data is contradictory, other authors like Yamamoto suggest that there are no differences in incidence while Atwell et al. has indicated a higher incidence in males $(4,16,17)$. In our study, the male gender seemed to be a risk factor for recurrences (10 out of 13) this event was probably due to the lower compliance of male patients, but also to the higher overall incidence in the complete group: 29 of the 37 patients investigated were males. Besides the non-modifiable risk factors of recurrence quoted in literature such as gender, among those that can be influenced, smoking seems to increase the risk of relapse. It is also recognized that smokers are three times more likely to develop $\mathrm{CD}$. Sutherland et al. identified the fact that the 10-year reoperation risk revolves around 70\% for smokers compared to nonsmokers who have a $40 \%$ risk $(p=0.007)(18,19)$. Moreover patients who quit smoking are less likely to undergo repeat surgery for recurrence. In our study the majority of patients were smokers identified during the first intervention but do the lack of followup data we could not assess how many had quit after recomandation and the impact it had on the disease evolution. In conclusion, smoking can reduce on one hand the incidence of $\mathrm{CD}$ but quiting can dramatically alter the future evolution of the disease into the better.

Regarding the relationship between age and postoperative complications while keeping in mind previous results obtained from studies which evaluated the relantioship between age and CD, we introduced our patients into two groups using the 50 years old as cuttoff limit as such: 20-50 years, and above 50 years to try to see how and if age influnences the reccurence rate in CD. Literature suggests that elderly patients in CD tend to have a better evolution of the disease. Several explenations have been proposed - first, it has been reported that older patients adhere better to their treatment regimens than younger age groups. Younger patients tend to have lower compliance with medication than older patients because they put more importance on personal and social goals $(20,21)$. But other unmodiafiable factors have been sugessted: the relatively immunodeficient state due to age-related changes in the middle-old group may weaken the aberrant immune response that would characterize continuous disease flares and perhaps expedite a better responses to medical therapy, leading to an improved disease course (22). Indeed our results are in line with literature, the majority of patients with relapse and surgery were in the 20-50 years old subgroup, so 8 out of the 13 relapses were in this subgroup.

The rate of endoscopic recurrence in CD reaches $70 \%$ at 1 year after surgery, which can lead to clinical manifestations, complications and eventually reintervention $(23,24,25)$. Postoperative microscopic recurrence at the level of the anastomosis can occur as early 7 days after surgery - identified by biopsy (26). The most common place of recurrence appears to be the neoterminal ileum - superior to the anastomosis in ileocolonic resections. A total of $30 \%$ of patients have a symptomatic relapse at 3 years from the intestinal resection, $50 \%$ at 5 years and $60 \%$ at 10 years. In our study, from the 13 cases of reccurence almost half of these were due to relapse located at the level of the ileotransverse anastomosis, thus reconfirming Sachar's observations (27). Considering the fact that the most frequent place of relapse is the anastomosis, in the case of patients who receive a stomy (colostomy, ileostomy) upstream from the anastomosis - the flow of faecal matter is diverted - and the recurrence rate is kept low but after these are abolished, aphtous ulcers characteristic to CD begin to develop $(28,29)$. It is considered that this relapse is triggered by the presence of intestinal content and bacteria in the intestinal lumen which attract inflammatory cells into the mucosa and, in turn trigger the lymphocyte activation cascade. In the subgroup of patients with reintervention only three cases had a stomy (ileostomy / colostomy) as the first intervention, in all other cases the surgeons opted for a anastomosis. Of the total group of patients operated in emergency, anastomosis was practiced in 24 cases, and in ten of them recurrence occured and surgery was required - 
possibly suggesting the detrimental effect the luminal content has on the intestinal mucosa in CD while only three patients with stomy relapsed. Perhaps when the clinical situation allows and the patient agrees, maybe stomy is the best option in CD emergency surgery (30).

Some of the postoperative recurrences could be prevented according to Rutgeerts by medical therapy with the help of two treatment strategies that seem to disrupt the natural evolution of $\mathrm{CD}, 1$ ) antibiotic treatment (nitromidazole) or 2) azathioprine (31). Highdose mesalazine prophylaxis is indicated for small segmental resections of the small intestine (32). For patients at risk of recurrence due to associated risk factors, elective treatment during the postoperative period should be represented by azathioprine / mercatopurine (32). Antibiotics such as imidazole have been shown to be useful when used after ileocolonic resections but are more difficult to tolerate by the patient (32). Probiotics have failed to show efficacy in postoperative CD recurrence, but should merit further investigations (17). Biologic therapy with infliximab or adalimumab can also play a role in reducing reccurence rates in these patients

The study presented has the limits of a retrospective study, it is not clear whether the patients have been prepared preoperatively properly, the evolution of the disease up to the time of surgery is difficult to appreciate and the clinical severity indices have a limited utility in the current practice. A problem commonly encountered in the analysis of follow-up data for CD patients is the lack of prospective, randomized randomized trials. All of this has led to a decrease in the quality of the meta-analysis results which try to evaluate the long-term impact of surgical interventions / reinterventions in CD. One of the causes of this variability / heterogeneity in outcomes is due to the small number of patients enrolled in these retrospective studies, and to the multiple causes that influence the postoperative outcome (33). So inclusion of a representative sample in a randomized trial of $\mathrm{CD}$ would probably require a very long trial. A solution to this problem can be represented by co-opting of several high-volume centers specialized in the treatment of CD patients and the creation of prospective, randomized databases with the subsequent generation of statistically significant results.

\section{Conclusion}

In conclusion the majority of patients with CD which require surgery have significant small bowel disease and are smokers. Our study shows that the one third of patients with CD will relapse with a median period from the first surgery of 2,3 years. Male gender, anastomosis without a diverting stoma and age under 50 years seems to increase the relapse rate. Medical treatment for $\mathrm{CD}$ patients in the postoperative period has an influential role regarding the relapse rate, as demonstrated by our study, corticoids increase the relapse rate while biologic therapy will decrease it.

\section{Authors' Contributions}

Mihaila D, Braga V, Tomescu L, gathered the data, Voiosu T, Constantinoiu S, designed the study, Slavu I, Alecu L, Tulin A, wrote the manuscript and performed the statistical analysis.

\section{Conflict of Interests}

The authors declare no conflict of interests.

\section{References}

1. Loftus EV Jr, Schoenfeld P, Sandborn WJ, The epidemiology and natural history of Crohn's disease in population-based patient cohorts from North America: a systematic review. Aliment Pharmacol Ther. 2002;16(1):51-60.

2. Silverstein MD, Loftus EV, Sandborn WJ, Tremaine WJ, Feagan BG, Nietert PJ, et al. Clinical course and costs of care for Crohn's disease: Markov model analysis of a population-based cohort Gastroenterology. 1999;117(1):49-57.

3. Canin-Endres J, Salky B, Gattorno F, Edye M. Laparoscopically assisted intestinal resection in 88 patients with Crohn's disease. Surg Endosc. 1999;13(6):595-9.

4. Chardavoyne R, Flint GW, Pollack S, Wise L. Factors affecting recurrence following resection for Crohn's disease. Dis Colon Rectum. 1986;29(8):495-502.

5. Tavernier M, Lebreton G, Alves A. Laparoscopic surgery for complex Crohn's disease. J Visc Surg. 2013;150(6):389-93. doi: 10.1016/j.jviscsurg.2013.09.004. Epub 2013 Oct 8.

6. Sica GS, Biancone L. Surgery for inflammatory bowel disease in the era of laparoscopy. World J Gastroenterol. 2013;19(16):2445- 
8. doi: 10.3748/wjg.v19.i16.2445.

7. Thia KT, Sandborn WJ, Harmsen WS, Zinsmeister AR, Loftus EV Jr. Risk factors associated with progression to intestinal complications of Crohn's disease in a population-based cohort. Gastroenterology. 2010;139(4):1147-55. doi: 10.1053/j.gastro.2010.06.070. Epub 2010 Jul 14.

8. Tiret E, Karoui M. Traitement chirurgical de la maladie de Crohn: principes de tactique et de technique opératoires. EMC Techniques chirurgicales appareil digestif 2006;40-667. Doi: 10.1016/S02460424(06)39771-3

9. Singh S, Al-Darmaki A, Frolkis AD, Seow CH, Leung Y, Novak KL, et al. Postoperative mortality among patients with infl ammatory bowel diseases: a systematic review and metaanalysis of population-based studies. Gastroenterology. 2015;149(4):928-37. doi: 10.1053/j. gastro.2015.06.001. Epub 2015 Jun 6.

10. Kennedy NA, Clark DN, Bauer J, Crowe AM, Knight AD, Nicholls RJ, et al. Nationwide linkage analysis in Scotland to assess mortality following hospital admission for Crohn's disease: 1998-2000. Aliment Pharmacol Ther. 2012;35(1):142-53. doi: 10.1111/j.13652036.2011.04906.x. Epub 2011 Nov 9.

11. Shaffer VO, Wexner SD. Surgical management of Crohn's disease. Langenbecks Arch Surg. 2013;398(1):13-27. doi: 10.1007/s00423012-0919-7. Epub 2012 Feb 21.

12. Cottone M, Rosselli M, Orlando A, Oliva L, Puleo A, Cappello M, et al. Smoking habits and recurrence in Crohn's disease. Gastroenterology. 1994;106(3):643-8.

13. Wettergren A, Christiansson J. Risk of recurrence and reoperation after resection for ileocolic Crohn's disease. Scand J Gastroenterol. 1991;26(12):1319-22.

14. Heimann TM, Greenstein AJ, Lewis B, Kaufman D, Heimann DM, Aufses AH Jr. Comparison of primary and reoperative surgery in patients with Crohn's disease. Ann Surg. 1998; 227(4):492-5.

15. Williams JG1, Wong WD, Rothenberger DA, Goldberg SM. Recurrence of Crohn's disease after resection. Br J Surg. 1991; 78(1):10-9.

16. Yamamoto T. Factors affecting recurrence after surgery for Crohn's disease. World J Gastroenterol. 2005;11(26):3971-9.

17. Atwell JD, Duthie HL, Goligher JC. The outcome of Crohn's disease. Br J Surg. 1965 Dec;52(12):966-72.

18. Ryan WR, Allan RN, Yamamoto T, Keighley MR. Crohn's disease patients who quit smoking have a reduced risk of reoperation for recurrence. Am J Surg. 2004;187(2):219-25.

19. Sutherland LR, Ramcharan S, Bryant H, Fick G. Effects of cigarette smoking on recurrence of Crohn's disease. Gastroenterology. 1990;98(5 Pt 1):1123-8.

20. Horne R, Parham R, Driscoll R, Robinson A Patients' attitudes to medicines and adherence to maintenance treatment in inflammatory bowel disease. Inflamm Bowel Dis. 2009;15(6):837-44. doi: 10.1002/ ibd.20846.

21. Cervený P, Bortlík M, Kubena A, VIcek J, Lakatos PL, Lukás M Nonadherence in inflammatory bowel disease: results of factor analysis. Inflamm Bowel Dis. 2007;13(10):1244-9.

22. Dorshkind K, Montecino-Rodriguez E, Signer RA The ageing immune system: is it ever too old to become young again? Nat Rev Immunol. 2009:9(1):57-62. doi: 10.1038/nri2471.

23. Lock MR, Farmer RG, Fazio VW, Jagelman DG, Lavery IC, Weakley FL. Recurrence and reoperation for Crohn's disease: the role of disease location in prognosis. N Engl J Med. 1981;304(26):1586-8.

24. Rutgeerts P, Geboes K, Vantrappen G, Kerremans R, Coenegrachts JL, Coremans G. Natural history of recurrent Crohn's disease at the ileocolonic anastomosis after curative surgery. Gut. 1984;25(6):665-72.

25. McLeod RS, Wolff BG, Steinhart AH, Carryer PW, O'Rourke K, Andrews DF, et al. Risk and significance of endoscopic/radiological evidence of recurrent Crohn's disease. Gastroenterology. 1997;113(6):1823-7.

26. D'Haens GR, Geboes K, Peeters M, Baert F, Penninckx F, Rutgeerts P. Early lesions of recurrent Crohn's disease caused by infusion of intestinal contents in excluded ileum. Gastroenterology. 1998;114(2): 262-7.

27. Sachar DB. The problem of postoperative recurrence of Crohn's disease. Med Clin North Am. 1990;74(1):183-8.

28. Rutgeerts P, Goboes K, Peeters M, Hiele M, Penninckx F, Aerts R, et al. Effect of faecal stream diversion on recurrence of Crohn's disease in the neoterminal ileum. Lancet. 1991;338(8770):771-4.

29. Cameron JL, Hamilton SR, Coleman J, Sitzmann JV, Bayless TM. Patterns of ileal recurrence in Crohn's disease. A prospective randomized study. Ann Surg. 1992;215(5):546-51; discussion $551-2$.

30. D'Haens GR, Geboes K, Peeters M, Baert F, Penninckx F, Rutgeerts P. Early lesions of recurrent Crohn's disease caused by infusion of intestinal contents in excluded ileum. Gastroenterology. 1998; 114(2):262-7.

31. P Rutgeerts. Crohn's disease recurrence can be prevented after ileal resection. Gut 2002;51:152-154

32. Gionchetti P, Dignass A, Danese S, Magro Dias FJ, Rogler G, Laszlo Lakatos $P$, et al. 3rd European Evidence-based Consensus on the Diagnosis and Management of Crohn's Disease 2016: Part 2: Surgical Management and Special Situations. J Crohn's and Colitis, 2017;11(2):135-149. https://doi.org/10.1093/ecco-jcc/jjw169

33. Delaney J, Laws P, Wille-Jørgensen P, Engel A. Inflammatory bowel disease meta-evidence and its challenges: is it time to restructure surgical research? Colorectal Dis. 2015;17(7):600-11. doi: 10.1111/ codi.12882. 